\title{
Economics of Household Demand for African Breadfruit (Treculia Africana) in Owerri Agricultural Zone of IMO STATE, Nigeria
}

\author{
Ohajianya Donatus O. ${ }^{1}$, Osuafor Ogonna O. ${ }^{2}$
}

\author{
${ }^{1}$ Department of Agricultural Economics, Federal University of Technology, Owerri, Imo State, Nigeria. \\ ${ }^{2}$ Department of Agricultural Economics and Extension, Nnamdi Azikiwe University, Awka, Anambra State, Nigeria.
}

\begin{abstract}
The need to build up the knowledge of the current situation regarding the household demand for African breadfruit (Treculia africana) in Owerri Agricultural Zone of Imo State, Nigeria led to this study. The specific objectives of the study were to determine the household demand for African breadfruit and to estimate price, income and crossprice elasticities of demand for African breadfruit. One hypothesis was tested. Multi-stage random sampling technique was used in selecting sixty (60) households who consume breadfruit who were interviewed with a well structured questionnaire. Data collected were analysed using frequency distribution, percentages and elasticity of demand model. The findings of the study showed that the household demand for breadfruit is very high (63\%) in the study area. The mean quantity demanded per month was $7 \mathrm{~kg}$ (40 cups). Majority of the respondents consume $70 \%$ of their harvest. The result of multiple regression analysis showed that increase in household demand and price of substitute will lead to an increase in quantity demanded of African breadfruit. It was recommended that more farmers need to get involved in the production of breadfruit as it is highly demanded for its food and non-food uses.
\end{abstract}

Keywords- Analysis, household demand, African breadfruit.

\section{INTRODUCTION}

The African Breadfruit (Treculia africana) is an unbuttressed large tree, a representative of Moraceae (Akubor \& Obiegbuna, 2014). This non-timber forest product is a member of the mulberry family and one of the four members of the Genera, Treculia (Muojekwu, Ugwumba \& Chidebelu, 2017). It produces matures fruits during the hungry season (March-July) following the planting of major staples such as yam, maize, rice, cocoyam etc in Imo and Anambra states in Nigeria (Nwufo and Mba, 1990). The fruits attain $40 \mathrm{~cm}$ in diameter, weigh $8014 \mathrm{~kg}$ and contain many orange seeds of about $1 \mathrm{~cm}$ buried in spongy pulp. In Nigeria, African Breadfruit is very common in the Western and Eastern States. This forest product is given many names in various localities where it is found. The Ibos call it " $u k w a$ ", Yorubas "afon", Benin "ize", Efiks, Ibibios and Annangs "ediang". According to Okafor (2005), african breadfruit flour contains $4.05 \%$ protein, $76.70 \%$ carbohydrate and 331 calories.

The household demand for produced commodities is important to an economy because of its influence on the level of production. Households ultimately own in common all wealth, including resources that they make available to businesses or government. African breadfruit is a high employer of labour. It has several food and non-food potentials:- Confectionery: several products prepared from breadfruit flour include cookies, buns, cakes, soup thickening agent and weaning diet (Anazonwu-Bello in Okafor, 2005); Beverages: Ejiofor, Obiajulu and Okafor (2012) prepared a non-alcoholic beverage from breadfruit seeds and was found acceptable when taken without milk and sugar; Livestock feeds: the fruit head pulp (mesocarp) and the bran (pericarp) are used for livestock feed formulation (Okafor, 2005); Fibre: breadfruit wood is useful in pulp and paper making (Uju \& Ugwuoke, 1996); Fuel: the wood is suitable for firewood and charcoal; and Medicinal uses: for curing malaria, cough, rheumatism, diabetes and leprosy (Nwabueze, 2006; Muojekwu et al., 2017). African breadfruit oil can be used for making soaps and hair shampoo (Ajiwe, Okeke \& Agbo in Akintayo \& Bayer, 2002).

\section{Problem Statement}

African breadfruit has restricted distribution, sparse density and is threatened with extinction, yet it has a high potential for selection and genetic improvement. It is currently included in the list of endangered species of Southern Nigeria and this is quite worrisome (Nuga \& Ofodile, 2010). The output of this important crop is continuously declining to the extent that the household demand for it is no longer met. 
Limited studies have been made on African breadfruit with respect to its demand by households and this has created a gap in knowledge. The need to fill this gap led to this study. The study is therefore expected to provide answers to these questions: What is the household demand for African breadfruit? What is the nature of the price, income and crossprice elasticity of demand for breadfruit by households in the study area?

\section{OBJECTIVES OF THE STUDY}

The specific objectives of the study were to:

1. determine the household demand for African breadfruit and

2. estimate price, income and cross-price elasticities of demand for African breadfruit.

\section{Hypothesis of the Study}

One hypothesis was tested in the study:

Household demand for African breadfruit is price inelastic in the study area.

\section{Theoretical Framework}

The demand theory is applicable to this study. It is vital to distinguish three possible uses of demand theory. The first use is to study the aggregate behavior of all households. The second use is to make statements about an individual household's possible actions. The third is to make statements about what each household will certainly do (Lipsey ..., 1990). The assumption of household irrational behavior applies primarily to the third use of demand theory.

\section{METHOD}

The study was conducted in Owerri Agricultural Zone of Imo State, Nigeria. Owerri Agricultural Zone is one of the three Agricultural Zones in Imo State.. The breadfruit producing areas of Imo State lie within longitude $6^{0} 50^{1} \mathrm{E}$ and $7^{0} 25^{1} \mathrm{E}$ and latitude $4^{0} 45^{1} \mathrm{~N}$ and $7^{0} 15^{1} \mathrm{~N}$ (Udo, 1993). The study adopted a descriptive survey design. Multi-stage random sampling technique was used for sample selection. The study was carried out in four Local Government Areas (LGAs) out of the eleven (11) LGAs in the study area. The LGAs are Ohaji/Egbema, Ngor Okpala, Ikeduru and Ezinihitte Mbaise. Sixty (60) household heads formed the sample of the study. A 33-item researcher-developed questionnaire was validated by three experts and used for data collection. A pre-test was conducted to improve the reliability of the questionnaire used for the study. Data were analysed using frequency distribution, percentages and Ordinary Least Squares (OLS) multiple regression model.

Model Specification

Ordinary Least Squares (OLS) Multiple Regression Model
To estimate the price, income and cross-price elasticity of demand for African breadfruit, the variables were analysed and tested by first fitting the OLS multiple regression model to the demand function. The demand function is specified implicitly as follows:

$\mathrm{Q}_{\mathrm{d}}=\mathrm{f}(\mathrm{Pb}, \mathrm{Yh}, \mathrm{Ps}, \mathrm{e})$

Where: $\mathrm{Q}_{\mathrm{d}}=$ Quantity of African breadfruit demanded (kg/month)

$$
\begin{aligned}
& \mathrm{Pb}=\text { Price of breadfruit }(\mathrm{N}) \\
& \mathrm{Yh}=\text { Household income }(\mathrm{N}) \\
& \mathrm{Ps}=\text { Price of substitute (beans) } \\
& \mathrm{e}=\text { error term }
\end{aligned}
$$

It is expected a priori that the coefficients of $\mathrm{Yh}, \mathrm{Ps}>0 ; \mathrm{Pb}<0$. Four functional forms: linear, exponential, double-log and semi$\log$ were fitted into the model. The functional form that best fits the regression line, according to economic, statistical and econometric criteria was selected as the lead equation.

The parameter estimates of each model gave the Marginal Physical Product (MPP) as the regression result. The elasticity of demand (Ed) was obtained by dividing the MPP by the Average Product (AP) as shown:

$$
E d=\frac{\mathrm{MPPx}}{\mathrm{APx}}
$$

Elasticity of demand is derived from the parameter estimates as follows:

$$
\begin{gathered}
E p=\frac{\text { Percentage change in quantity demanded }}{\text { Percentage change in price }} \\
E i=\frac{\text { Percentage change in quantity demanded }}{\text { Percentage change in income }} \\
E x y=\frac{\text { Percentage change in quantity } x}{\text { Percentage change in price } y}
\end{gathered}
$$

Where:

$E p=$ Price elasticity of demand

$E i=$ Income elasticity of demand

$E x y=$ Cross-price elasticity of demand

If the elasticity of demand for African breadfruit is greater than $1(\mathrm{Ed}>1)$, it means that demand is elastic. If it is less than $1(\mathrm{Ed}<1)$, it means that demand is inelastic and if it is equal to $1(E d=1)$, it means that demand is constant.

\section{RESULTS AND DISCUSSION}

The results of field survey were presented according to the objectives of the study as follows:

Objective 1: Determine the household demand for African breadfruit

The distributions of breadfruit consumers according to frequency of breadfruit consumption, rate of demand for breadfruit and quantity of breadfruit demanded per month are presented in Table 1 
Rate of demand for breadfruit

Quantity (kg) of breadfruit demanded by households Mean $=7.0 \mathrm{~kg}$ (40 cups)

Table.1: Quantity of breadfruit demanded by households

\begin{tabular}{|c|c|c|c|}
\hline \multicolumn{2}{|c|}{ Quantity demanded } & \multirow{2}{*}{$\begin{array}{l}\text { Frequency } \\
6\end{array}$} & \multirow{2}{*}{$\begin{array}{l}\text { Percentage } \\
10\end{array}$} \\
\hline Frequency of breadfruit consumption & Once a week & & \\
\hline & Once in two weeks & 21 & 35 \\
\hline & Twice a week & 13 & 22 \\
\hline & Rarely (not often) & 6 & 10 \\
\hline & Often (frequently) & 14 & 23 \\
\hline \multirow[t]{5}{*}{ Rate of demand for breadfruit } & Very high & 38 & 63 \\
\hline & High & 16 & 27 \\
\hline & Average & 6 & 10 \\
\hline & Low & 0 & 0 \\
\hline & Very low & 0 & 0 \\
\hline Quantity (kg) of breadfruit demanded by & $\leq 4.9$ & 34 & 57 \\
\hline \multirow[t]{3}{*}{ households Mean $=7.0 \mathrm{~kg}(40$ cups $)$} & $5.0-14.9$ & 22 & 37 \\
\hline & $15.0-24.9$ & 2 & 3 \\
\hline & $25.0-34.9$ & 2 & 3 \\
\hline
\end{tabular}

Table 1 shows that most (35\%) of the breadfruit consumers eat breadfruit twice a week and $23 \%$ eat it often. Majority $(63 \%)$ of the breadfruit consumers rate the demand for breadfruit as very high and none of them rated the demand for breadfruit as low or very low. Majority (57\%) of the breadfruit consumers demand $4.9 \mathrm{~kg}$ of breadfruit and below, $37 \%$ of them demand up to an average of $7 \mathrm{~kg}$ while $3 \%$ demand up to $15-35 \mathrm{~kg}$ of breadfruit per month. These findings reveal that the demand for breadfruit is high in the study area. Again, it may be possible that breadfruit is expensive in the study area thereby limiting the quantity purchased in the market.

The distributions of breadfruit consumers according to quantity of breadfruit harvest consumed and sold per month are presented in Figures 1 and 2.

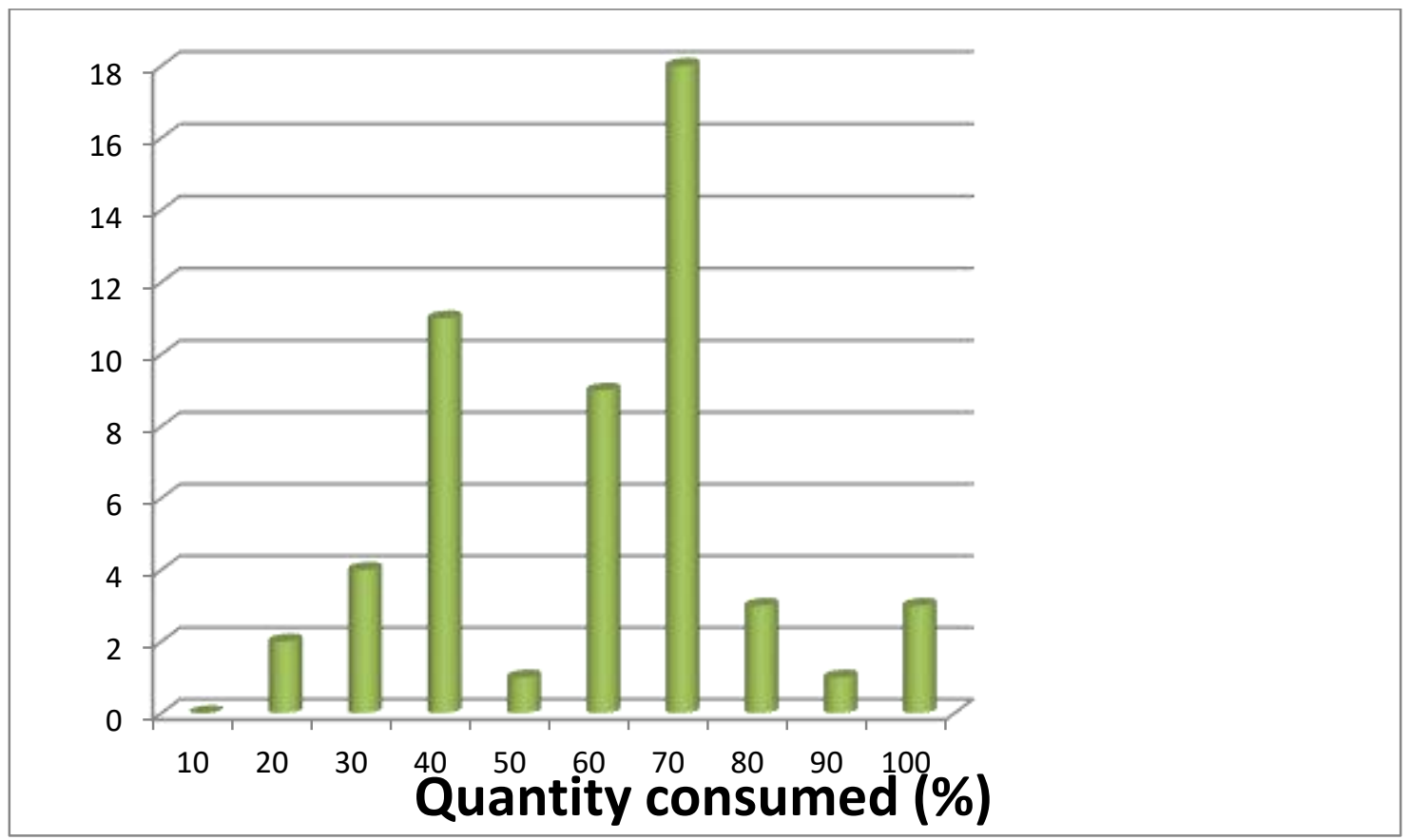

Fig.1: Bar chart showing quantity of breadfruit harvest consumed per month

Figure 1 shows that majority (18 persons) of the breadfruit consumers consume much $(70 \%)$ of their harvest, 11 persons consume $40 \%, 9$ consume $60 \%, 4$ persons $30 \%, 3$ persons $80 \%, 3$ persons also consume $100 \%$ of their 
harvest, 2 persons $20 \%$ and 1 person consume $50 \%$ and $90 \%$ respectively. Six (6) persons do not own any breadfruit tree. The chart reveals that a greater number of breadfruit consumers prefer to consume it than to sell it. This implies that demand outweighs supply.

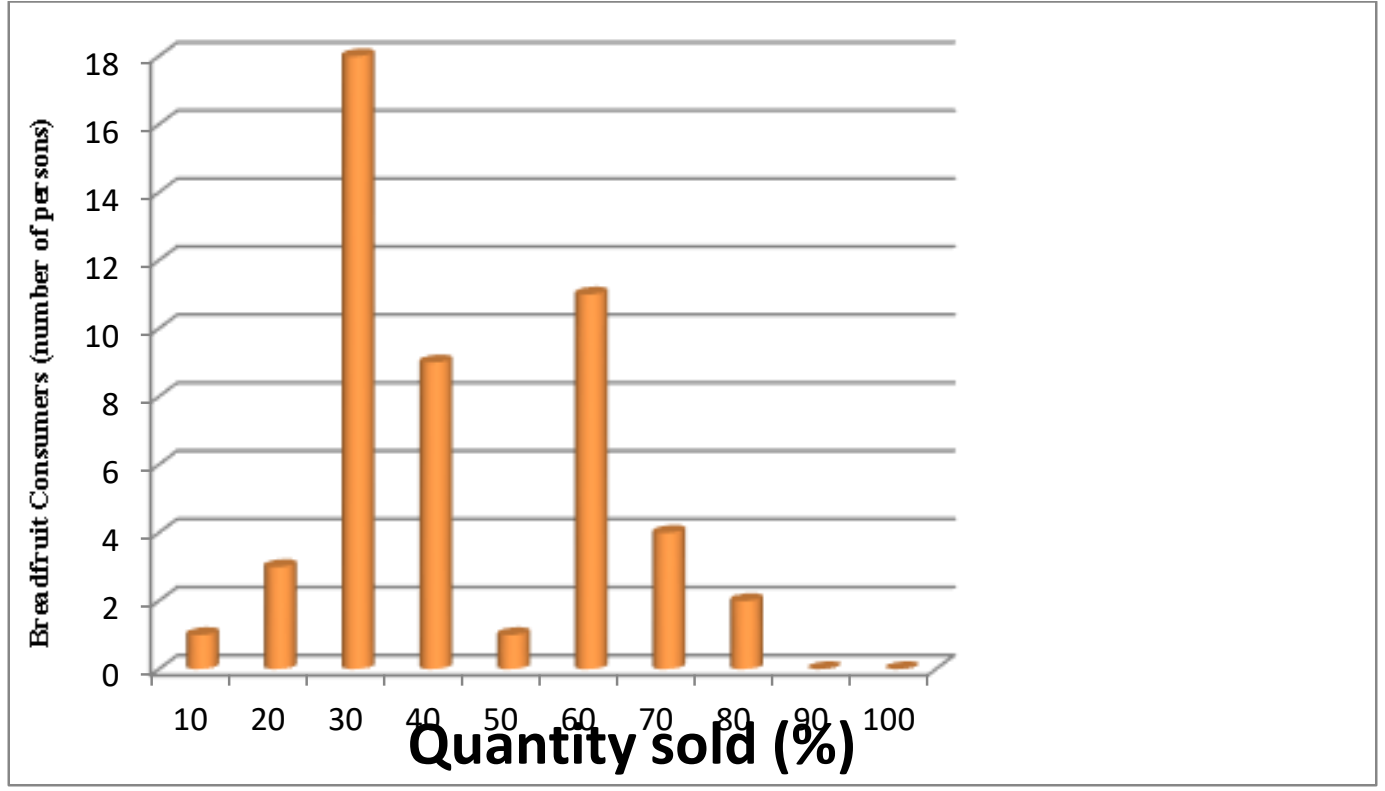

Fig.2: Bar chart showing quantity of breadfruit harvest sold per month

Figure 2 shows that majority (18 persons) of the breadfruit consumers sell (30\%) of their harvest, 11 persons sell $60 \%$, 9 persons $40 \%$, 4 persons $70 \%, 3$ persons $20 \%, 2$ persons $80 \%$ and 1 person sell $10 \%$ and $50 \%$ respectively. 3 persons do not sell their harvest at all and 6 persons do not own any breadfruit tree. The chart reveals that a lesser number of breadfruit consumers prefer to consume it than to sell it. This implies that demand outweighs supply.

Objective 2: Estimation of price, income and cross-price elasticities of demand for African breadfruit.

The relationship between quantity of breadfruit demanded and demand factors is shown in table 1.

Table.1: Results of OLS multiple regression analysis on relationship between quantity of breadfruit demanded and demand factors

\begin{tabular}{|c|c|c|c|c|}
\hline Explanatory Variables & $\begin{array}{l}\text { Linear } \\
\text { Function }\end{array}$ & $\begin{array}{l}\text { Semi-log } \\
\text { Function }\end{array}$ & $\begin{array}{l}\text { Double-log } \\
\text { Function }\end{array}$ & $\begin{array}{l}\text { Exponential } \\
\text { Function }\end{array}$ \\
\hline Price of Breadfruit $\left(\mathrm{P}_{\mathrm{b}}\right)$ & $\begin{array}{l}-9.8417 \\
(1.1981)\end{array}$ & $-1.5266(1.0969)$ & $\begin{array}{l}-0.6839 \\
(3.3941)^{* *}\end{array}$ & $\begin{array}{l}-0.0072 \\
(2.6667)^{* * *}\end{array}$ \\
\hline Household Income (Yh) & $\begin{array}{l}7.1904 \\
(2.3152)^{*}\end{array}$ & $2.5328(1.0374)$ & $0.8136(3.6698)^{* *}$ & $0.0066(2.4444) *$ \\
\hline Price of Substitute (Ps) & $\begin{array}{l}5.1186 \\
(1.1148)\end{array}$ & $0.5912(1.2073)$ & $0.1942(2.3887)^{*}$ & $\begin{array}{l}0.0064 \\
(1.0847)\end{array}$ \\
\hline Constant & 176.0039 & 104.4127 & 91.4303 & 83.1014 \\
\hline $\mathrm{R}^{2}$ & 0.4922 & 0.3928 & 0.8126 & 0.6421 \\
\hline Std Error & 17.5213 & 16.5513 & 0.0318 & 0.0892 \\
\hline F-Value & $18.0293 * *$ & $12.1235 * *$ & $82.0808 * *$ & $33.4427 * *$ \\
\hline Sample Size & 60 & 60 & 60 & 60 \\
\hline
\end{tabular}

Figures in parenthesis are the t-ratio

* = t-ratio significant at $5 \%$

$* *=\mathbf{t}$ and $\mathbf{f}$-ratios significant at $\mathbf{1 \%}$
Table 1 shows the results obtained in four functional forms. The functional form that produced the highest value of coefficient of multiple determination $\left(\mathrm{R}^{2}\right)$, highest number of significant variables (at $1 \%$ and $5 \%$ ), highest F-value and 
conformity to a priori expectations was selected as the lead equation. Based on these, the double-log functional form was selected as the lead equation for discussion.

The coefficient of multiple determination as shown in table 1 is 0.8126 . This implies that $81 \%$ of the variation in quantity of breadfruit demanded can be accounted for by the joint action of the explanatory variables investigated in the study. The three demand factors included in the model were significant at at $1 \%$ and 5\% levels of probability. The coefficients of household income (Yh) and price of substitute (Ps) were significant and positive while the coefficient of price of breadfruit $(\mathrm{Pb})$ was significant but negative. This result implies that increase in $\mathrm{Yh}$ and Ps will lead to an increase in quantity of breadfruit demanded while increase in $\mathrm{Pb}$ will lead to a decrease in quantity demanded.

Hypothesis: Household demand for African breadfruit is price inelastic in the study area.

The results of computed price, income and cross-price elasticities of demand are shown in table 2. The table was derives from table 1 where the double-log function gave the lead equation.

Table.2: Computation of Elasticities of Demand

\begin{tabular}{|c|c|c|c|c|}
\hline Demand Factor & $\begin{array}{l}\text { Marginal } \\
\text { Product (MPP) }\end{array}$ & Physical & $\begin{array}{l}\text { Elasticities } \\
\text { of Demand }\end{array}$ & Classification \\
\hline Price of breadfruit $(\mathrm{Pb})$ & -0.684 & & -0.684 & Inelastic \\
\hline Household income (Yh) & 0.814 & & 0.814 & Necessity \\
\hline Price of substitute (Ps) & 0.194 & & 0.194 & Substitute \\
\hline
\end{tabular}

In a double logarithmic function, the coefficients of regression (MPP) are also elasticities (Ohajianya \& Onyenweaku, 2002). Table 2 shows that the price elasticity of demand for breadfruit is -0.684 which is inelastic demand and implies that if the price of African breadfruit increases, its demand would fall. The income elasticity of demand for breadfruit is 0.814 . The value of income elasticity is positive and less than unity, hence breadfruit is classified as a necessity. The cross-price elasticity of demand for breadfruit represented by the price of substitute is 0.194. Since the cross-price elasticity value is positive, the commodity that had the price is a close substitute to breadfruit in the study area.

Therefore, the hypothesis is accepted.

\section{CONCLUSION}

The household demand for African breadfruit for diverse usage constitutes a useful ground upon which farmers can expand production. To sustain optimum demand for African breadfruit by households, more farmers need to get involved in the production of breadfruit as it is highly demanded for its food and non-food uses.

\section{REFERENCES}

[1] Akintayo, E.T. \& Bayer, E. (2002). Characterisation and some possible uses of Plukenetia conophora and Adenopus breviflorus seeds and seed oils. Bioresource technology, 85(1), 95-97.

[2] Akubor, P.I. \& Obiegbuna, J.E. (2014). Effect of Processing Methods on the Quality of Flour and Bread from African Breadfruit Kernel Flour. Food Science and Quality Management, 24. 32-41.

[3] Ejiofor, M.A.N., Obiajulu, O.R. \& Okafor, J.C. (2012). Diversifying utilities of African breadfruit as food and feed. International Tree Crops Journal, 5(3), 125-134.

[4] Muojekwu, C.A., Ugwumba, C.O.A. \& Chidebelu, S.A.N.D. (2017). Marketing of African breadfruit seeds (Treculia Africana) in Anambra state, Nigeria. Scholars Journal of Agriculture and Veterinary Sciences, 4(4), 167-174.

[5] Nuga, O.O. \& Ofordile, E.A.U. (2010). Potential of Treculia african Decne: An endangered species of Southern Nigeria. Journal of Agricultural and Social Research, 10(2), 91-99.

[6] Nwabueze, T.U. (2006). Effect of hydration and screw speed on the nutrient and acceptability of extruded ready-to-eat African breadfruit (Treculia africana) snack. Nigerian Food Journal, 24(1), 107-112.

[7] Ohajianya, D.O. \& Onyenweaku, C.S. (2002). Farm size and Relative Efficiency in Nigeria: Profit Function Analysis of Rice Farmers. Journal of Association for Advancement of modeling and simulation Techniques in Enterprises, France, 23(1), $1-16$.

[8] Okafor, J.C. (2005). Value addition and commercialization of plants and plant products developed through biotechnology approaches. pp. 413. 
[9] Onyemauwa, C.S. (2012). Analysis of women participation in cassava production and processing in Imo State, Southeast Nigeria. Journal of Economics and Sustainable Development, 3(5), 81-90.

[10] Ugwu, F.M. \& Oranye, N.A. (2006). Effects of some processing methods on the toxic components of African breadfruit (Treculia Africana). African Journal of Biotechnology, 5(22), 2329-2333. Available online at https://www.ajol.info/index.php/ajb/ article/view/55989/44445.

[11]Uju, G.C. \& Ugwuoke, C.E. (1996). Studies on the dimensions and suitability of wood fibres of selected tree species of the family 'moraceae' in paper making. Nigerian Journal of Botany,9(10),7-13. 